\begin{tabular}{|c|c|c|}
\hline$\underset{P U B L I C A T I O N}{\operatorname{NNF}}$ & $\begin{array}{l}\text { International Journal of Advanced Engineering, Management } \\
\text { and Science (IJAEMS) } \\
\text { ISSN: 2454-1311 } \\
\text { Vol-7, Issue-1; Jan, } 2021 \\
\text { Journal Home Page Available: } \text { https://ijaems.com/ } \\
\text { Journal DOI: } \text { https://dx.doi.org/10.22161/ijaems } \\
\text { Article DOI: } \text { https://dx.doi.org/10.22161/ijaems.71.5 }\end{array}$ & (1) \\
\hline
\end{tabular}

\title{
Development of Textbooks Based on Local Wisdom for Character Building of Elementary Education Students
}

\author{
Efendi Napitupulu, Hamonangan Tambunan, Nono Sebayang
}

Engineering Faculty Lecturer, State University of Medan, Indonesia

Received: 23 Nov 2020; Received in revised form: 03 Jan 2021; Accepted: 20 Jan 2021; Available online: 27 Jan 2021 (C)2021 The Author(s). Published by Infogain Publication. This is an open access article under the CC BY license (https://creativecommons.org/licenses/by/4.0/).

\begin{abstract}
Character is easily understood as characteristic-good values (knowing the value of goodness, wanting to do real good, having a good life, and having a good impact on the environment) which are embedded in oneself and are embodied in behavior. Coherently, character emanates from the results of thinking, heart, exercise, and feeling and intention of a person or group of people. Character is a characteristic of a person or group of people who contain values, abilities, moral capacities, and courage in facing difficulties and challenges. Character is synonymous with morals, so that character is the universal values of human behavior that include all human activities, both in relation to God, with oneself, with fellow humans, and with the environment, which are manifested in thoughts, attitudes, feelings, words, and actions based on religious norms, law, karma, culture, and customs as a form of local wisdom where students are.

Learning activities are a form of transferring subject matter that can change the mindset and behavior of students as outlined in textbooks. The textbook in question has been prepared based on local culture and wisdom, as well as to be implemented in student learning activities. This knowledge transfer pattern is included in a learning activity designed and developed in accordance with individual characteristics and learning objectives. The developed textbooks based on culture and local wisdom give decent results to be used in building student character.
\end{abstract}

Keywords-Textbooks, Culture and Local Wisdom, Student Character.

\section{INTRODUCTION}

The Industrial Revolution 4.0 has entered a new chapter. Various industries are starting to touch the virtual world, in the form of human, machine and data connectivity, which is better known as the Internet of Things (IoT). The development of science and technology has changed the face of world civilization. However, it needs to be realized that current and future technological advances are able to change the character of students in a direction that violates the norms and culture that have been maintained.

National character development can be defined as an effort to improve the quality of collective national behavior that is distinctive whether it is reflected in the awareness, understanding, taste, intention and behavior of the nation and state as a result of thinking, exercising heart, feeling and intention, as well as one's sports or group of people. National character development is a collectivesystemic effort of a nation-state to realize the life of the nation and state in accordance with the basis and ideology, constitution, state direction and collective potential in the context of civilized national, regional and global life to form a strong, competitive nation, have noble character, moral, tolerant, mutual cooperation, patriotic, dynamic, cultured, and science-oriented based on Pancasila and imbued with faith and piety to God Almighty. 


\section{LITERATURE REVIEW}

According to Lickona (1991), character is related to moral concepts (moral knowing), moral attitudes (moral felling), and moral behavior (moral behavior). Based on these three components, it can be stated that good character is supported by knowledge of goodness, the desire to do good, and do good deeds. Furthermore, it states "Character education develops these virtues through every phase of school life. In our work, we promote what we call a comprehensive approach to character education. Our classroom components include the teacher as model, developing a moral classroom community, positive peer relationships, using discipline as a tool for character development, and building a democratic classroom so the children are involved in helping to make decisions to solve real classroom problems."

Ryan and Bohlin (1999) wrote "Character education, then, with its twin goals of intellectual and moral development, should be implicit in all of the school's undertakings." (a) integrated approach in all subjects, (b) cultural development of educational units, (c) implementation of co-curricular and extracurricular activities, and (d) habituation of behavior in life within the educational unit. Character building through schools is carried out from early childhood education to higher education.

The results of the research by Bernninga, Berkowitz, Kuehn, and Smith (2003) found that there was a positive relationship between three specific indicators of character education and academic achievement. Lickona and Davidson (2005) reported the results of their research that community members as one of the eight strengths of character and service-learning as an effective strategy for increasing goal achievement.

One of the keys to the success of the character development program in educational units is the role model of educators and education personnel. Exemplary is not just an example for students, but also as a moral reinforcer for students in attitude and behavior. Therefore, the implementation of exemplary in the educational unit is a prerequisite in developing the character of students.

Lave and Wenger (1991) and Wenger (1998) describe the importance of social participation and active involvement in learning, suggesting that learning in a community is an important element, in effect promoting community learning for online teaching. The virtual community of students recognizes the importance of students taking an active role, building their understanding and understanding new information even though there is no face-to-face instruction. Garrison and Cleveland-Innes (2005) advocate for a community of learners around the integration of cognitive, social, and teaching presence towards high-level learning while engaging students in critical reflection and discourse (i.e., critical inquiry): "the reflective and collaborative nature of asynchronous, online learning. text-based approaches are well adapted to deep learning (i.e., cognitive presence).

\section{RESEARCH METHODS}

Product development techniques use the Research and Development (R\&D) method $R \& D$ is a development method for developing and evaluating learning programs, processes, and learning products.Data collection techniques in this study were observation and questionnaire distribution to material experts, media experts, linguists and users.

The research and development procedure uses a model developed by Robert Maribe Branch, based on the educational philosophy of the application of ADDIE must be student center, innovative, authentic and inspiring. The process stages in the ADDIE model are related to one another, therefore the use of this model needs to be done gradually and thoroughly to ensure the creation of an effective learning product. ADDIE is an acronym for Analyze, Design, Develop, Implement, and Evaluate (Branch, 2009). The application of the main steps in research is not only according to the original version but according to the characteristics of the subject.

\section{Teaching Material Development}

The design of textbooks is based on the content of national character building. In terms of terminology, the meaning of character was put forward by Thomas Lickona, who defined character as "A reliable inner disposition to respond to situations in a morally good way." Furthermore, Lickona added, "Character so conceived has three interrelated parts: moral knowing, moral feeling, and moral behavior" (Lickona, 1991: 51). Noble character (good character), in Lickona's view, includes knowledge of goodness (moral khowing), then creates commitment (intention) to goodness (moral feeling), and finally actually doing good (moral behavior). In other words, character refers to a series of knowledge (cognitives), attitudes (attitudes), and motivation (motivations), as well as behavior (behavior) and skills (skills).

In the process of development and formation, a person's character is influenced by two factors, namely environmental factors (nurture) and innate factors (nature). Psychologically, character behavior is a manifestation of one's potential Intelligence Quotient (IQ), Emotional Quotient (EQ), Spiritual Quotient (SQ), and Adverse Quotient (AQ) that a person has. The character 
configuration in the context of the totality of psychological and socio-cultural processes can ultimately be grouped into four categories, namely 1) spiritual and emotional development, 2) intellectual development, 3) sports and kinesthetic (physical and kinesthetic). development, and 4) affective and creativity development. These four psychosocial processes are holistically and coherently interrelated and complementary in the context of character building and the manifestation of noble values in a person.

\section{RESEARCH RESULT}

The results of the development research are in the form of a textbook "Character Building based on Culture and Local Wisdom". The making of this textbook is adjusted to the curriculum and syllabus of elementary schools.In accordance with the discussion on research methods, the development of this textbook uses the ADDIE method (Analyze, Design, Development, Implementation, Evaluation). The stages of developing a Textbook based on research results according to the ADDIE model are as follows:

Analysis Stages: Performance analysis is carried out to identify and classify problems that exist in school so far. At the analysis stage, initial preparation or preparation for development is carried out. Textbook needs analysis was carried out by interview and observation. Based on observations, it is known that it is necessary to make a Textbook "Character Building Based on Culture and Local Wisdom" which has been adapted to the curriculum as a source of student learning.

The initial stage is carried out with a needs analysis, namely determining the teaching materials needed by students to build student character. Thus the textbook "Character Building Based on Culture and Local Wisdom" is felt to increase the independence of students to learn independently in studying the material in the textbook "Character Building Based on Culture and Local Wisdom".

Design Stages: The design stage is a series of activities to make an initial draft of a textbook for learning. These stages are:a. Initial Design. At this stage the researcher designs the layout design that will be used. The material manuscript is written in Microsoft Word using A5 paper $(14.8 \mathrm{~cm} \times 21 \mathrm{~cm})$. The script is written in Times New Roman font with a text size of 12 and $1.15 \mathrm{~cm}$ between lines.b. Compilation of Material. At the material preparation stage, determining the scope of the textbook material to be developed and adjusted to the syllabus of the curriculum.

Development Stages: At the development stage, development steps are carried out, namely product manufacture, product feasibility validation and product revision. The appropriateness of the textbooks that have been made can be seen through the results of validation by experts (expert appraisal). Through validation of experts using a questionnaire, data is obtained. The data obtained in the form of qualitative data then converted into quantitative data by adding up the scores. Products that have been validated by media experts and material experts will then be used at the implementation stage or product testing. Validation of material experts was carried out by experts in character and character education subject matter. The research results can be seen in the following table.

Table 1. Average Material Expert Validation Results

\begin{tabular}{|l|l|c|}
\hline \multicolumn{1}{|c|}{ No. } & \multicolumn{1}{|c|}{ Statement } & Average \\
\hline Self Intruction & 5 \\
\hline 1. & Learning objectives are in accordance with the basic competencies in the syllabus. & 5 \\
\hline 2. & The learning objectives are in accordance with the indicators in the material. & 4,5 \\
\hline 3. & The material in the Textbook is in accordance with the required competencies. & 4,5 \\
\hline 4. & Material packaging helps students understand the lesson. & 4 \\
\hline 5. & The material in the Textbook helps students solve problems in subjects. & 5 \\
\hline 6. & The material in the Textbook is packaged coherently. & 5 \\
\hline 7. & The questions in the Textbook are in accordance with the learning material. & 4 \\
\hline 8. & The material is easy to understand for students. & 4 \\
\hline 9. & The material makes students learn independently. & 5 \\
\hline 10. & The material in the Textbook is supported by pictures to complement the material. & 5 \\
\hline 11. & The material is organized in a systematic order. & \\
\hline
\end{tabular}




\begin{tabular}{|c|c|c|}
\hline 12. & The language used in the Textbook is easy for students to understand. & 4 \\
\hline 13. & Exercise questions lead students to study independently. & 4 \\
\hline 14. & Practice questions are easy to do. & 4 \\
\hline & Score $(\mathbf{x})$ & 63 \\
\hline \multicolumn{2}{|c|}{ Self contained } & \\
\hline 15 . & The compatibility of the material in the Textbook with the syllabus. & 4,5 \\
\hline 16. & The suitability of the Textbook material with the required competencies. & 5 \\
\hline 17. & $\begin{array}{l}\text { The accuracy of the Textbook material in containing all the competencies needed by } \\
\text { students. }\end{array}$ & 4,5 \\
\hline & Score $(\mathbf{x})$ & 14 \\
\hline \multicolumn{2}{|c|}{ Stand alone } & \\
\hline 18. & The material in the Textbook can be studied without the help of another Textbook. & 4 \\
\hline & Score $(\mathbf{x})$ & 4 \\
\hline \multicolumn{2}{|c|}{ Adaptive } & \\
\hline 19. & $\begin{array}{l}\text { Textbooks can be used in accordance with developments in technology and } \\
\text { information. }\end{array}$ & 4 \\
\hline 20. & Textbooks can be used inside or outside the classroom. & 4 \\
\hline & Score $(x)$ & 8 \\
\hline \multicolumn{2}{|c|}{ User friendly } & \\
\hline 21. & The structure in the Textbook is easy to understand. & 4 \\
\hline 22. & The pictures in the Textbook show the clarity of the material. & 5 \\
\hline \multirow{2}{*}{\multicolumn{2}{|c|}{$\begin{array}{cc} & \text { Score (x) } \\
\text { Amount Average } & \end{array}$}} & 9 \\
\hline & & 98 \\
\hline
\end{tabular}

Based on the overall user assessment criteria with a score of (x) 98 getting the predicate "Very Good".

Implementation Stages:At this stage of implementation, product trials are conducted to determine the feasibility of textbooks that have been developed and revised by experts. Product trials were carried out online by filling out a user questionnaire. The trial was conducted on 15 students using a device in the form of a laptop or cellphone.

Product trials were carried out in steps: distributing the Textbook "Character Building Based on Culture and Local Wisdom" via Whatsapp in pdf form, conveying the aims and objectives of the researcher, distributing user questionnaires in the form of a google form link via Whatsapp and thanking students for the availability of students in product trials.

Textbook trials were conducted to determine student assessments of the developed learning Textbooks. Aspects assessed by students include; (1) the media aspect aims to see the ability of the textbook being developed to present effective and efficient learning, (2) the material aspect aims to measure the suitability of the material to the needs of students, (3) the language aspect aims to measure the level of ease of understanding the language used in Textbooks, and (4) aspects of the Textbook learning aim to measure the ability of the Textbooks to be developed in overcoming difficulties experienced by students in classroom learning activities. Data on the results of product trials using a questionnaire consisting of 22 questions. The data will then be analyzed to see students' responses regarding the feasibility of learning textbooks that have been developed before being used in their actual scope. The following are the results of the product trial. 
Table 2 Average Product Trial Results

\begin{tabular}{|c|c|c|}
\hline No. & Statement & Average Score \\
\hline \multicolumn{3}{|l|}{ Media } \\
\hline 1. & Textbook cover design is attractive. & 5 \\
\hline 2. & The writing on the cover provides information about the contents of the Textbook. & 4,4 \\
\hline 3. & The selection and combination of colors in the textbook passages are interesting. & 4,4 \\
\hline 4. & $\begin{array}{l}\text { The selection and combination of colors do not interfere with the readability of the } \\
\text { text in the Textbook. }\end{array}$ & 4,73 \\
\hline 5. & Pictures in the Textbook clarify the material being studied. & 4,73 \\
\hline 6. & The neatness and layout of the writing make it clear for students to read the material & 4,53 \\
\hline \multicolumn{3}{|l|}{ Theory } \\
\hline 7. & The material in the Textbook is in accordance with the required competencies. & 4,27 \\
\hline 8. & $\begin{array}{l}\text { The material in the Textbook helps students solve the problem of the availability of } \\
\text { learning resources. }\end{array}$ & 5 \\
\hline 9. & The material in the Textbook helps students in independent learning. & 4,73 \\
\hline 10. & Independent assignments are given in accordance with the material presented. & 4,2 \\
\hline \multicolumn{3}{|c|}{ Language } \\
\hline 11. & The language used in the textbook contents is easy to understand. & 4,53 \\
\hline 12. & The material in the Textbook is delivered in communicative language. & 4,67 \\
\hline \multicolumn{3}{|c|}{ Textbook Study } \\
\hline 13. & This Textbook helps students in learning. & 4,67 \\
\hline 14. & This Textbook helps students understand the learning material. & 4,6 \\
\hline 15. & This Textbook makes it easy to learn according to students' abilities. & 4,53 \\
\hline 16. & Students can focus more on learning using this Textbook. & 4,67 \\
\hline 17. & The questions in the Textbook make students better understand the learning material. & 4,2 \\
\hline 18. & Textbooks can shape students' independence in learning. & 4,6 \\
\hline 19. & Students use this Textbook as study material. & 4,4 \\
\hline 20. & Textbooks can be used anywhere and anytime to study. & 5 \\
\hline 21. & Textbooks can encourage motivation so that students want to read. & 4,73 \\
\hline 22. & Students feel happy when learning to use this Textbook. & 5 \\
\hline
\end{tabular}

Table 3 Product Trial Score

\begin{tabular}{|c|l|c|c|c|c|c|}
\hline No. & \multicolumn{1}{|c|}{ Aspect } & $\begin{array}{c}\text { Number } \\
\text { of Grains }\end{array}$ & Score (x) & $\begin{array}{c}\text { Maximum } \\
\text { Score }\end{array}$ & Average & $\begin{array}{c}\text { Percentage } \\
(\%)\end{array}$ \\
\hline 1. & Media & 6 & 26 & 30 & 4,3 & 86,67 \\
\hline 2. & Theory & 4 & 17 & 20 & 4,25 & 85 \\
\hline 3. & Language & 2 & 9 & 10 & 4,5 & 90 \\
\hline 4. & $\begin{array}{l}\text { Teaching } \\
\text { Textbook }\end{array}$ & 10 & 47 & 50 & 4,7 & 95 \\
\hline \multicolumn{2}{|c|}{ amount } & $\mathbf{2 2}$ & $\mathbf{9 9}$ & $\mathbf{1 1 0}$ & $\mathbf{4 , 4 4}$ & $\mathbf{8 9 , 1 7}$ \\
\hline
\end{tabular}


Based on the overall user assessment criteria with a score (x) of 99 and the percentage of eligibility to get the predicate "Very Good".

Evaluation Stages:In this evaluation stage, it analyzes data that has been assessed by experts and tested by users. The results of the data analysis stated that the textbook of learning "Character Building Based on Culture and Local Wisdom" was feasible to use with an average of the criteria "Good".Based on the results of the study, it was found that the use of teaching materials "Character Building Based on Culture and Local Wisdom" was suitable for building student character by $84.32 \%$

\section{DISCUSSION}

The assumptions and scope of this study revolve around the development of transformative learning models and innovations by applying a knowledge center to build student character in basic education units in North Sumatra. The development of student character as the nation's children aims to foster and develop the character of students so that they are able to realize a society that has one Godhead, fair and civilized humanity, has a spirit of Indonesian unity, has a community spirit led by wisdom of wisdom in representative deliberations, as well as social justice for all Indonesian people.

Building character is a process or effort carried out to foster, improve and or shape the character, character, psychiatric nature, morals (character), human beings (society) so that they show good character and behavior based on the values of Pancasila.

Teachers have a big role in providing knowledge. Moreover, teachers are considered as educated figures who are expected to be able to educate the nation's children for the future. But the hope is not only to educate and provide academic material at school. The teacher's role is more than that. Teachers are also expected to instill positive values in students, because teachers are role models for students. So, that's why teachers have a big role in shaping student character.

To support this, it is better if teachers also strengthen their character. Learning activities are held to shape character, build knowledge, attitudes and habits to improve the quality of life of students. On that basis, the importance of developing models and innovations in learning activities that empower all potentials to build student character. Transformative learning models and innovations are directed at encouraging the achievement of specific competencies and behaviors so that each individual is capable of being lifelong learners and realizing a learning society.
Thus it can be presumed that the development of transformative learning models and innovations brings students closer to learning, of course more and more and more complex, they do not only need theoretical knowledge only but really need knowledge on practical aspects in the form of skills or skills that are more competitive and real. With the rapid progress of social knowledge and communication technology, the very high transformation can affect changes in student character development. To instill a positive character in students, this will be a blueprint that will not be forgotten throughout his life. In addition, good character is one of the fundamental attitudes of a person's mindset and behavior to achieve a better life success. So it is appropriate for schools to prepare students with better characters who uphold culture and ethics as a provision for life in the future based on transformative learning models and innovations.

According to Gerlach \& Ely (1971), the word media in a broader understanding includes humans, materials, or events that build conditions in which students are able to acquire knowledge, skills, or attitudes. In this understanding, teachers, textbook content, and the school environment include the media. Furthermore, Gerlach \& Ely stated three characteristics of learning media, namely: 1) Fixative Property. This characteristic describes the ability of learning media to record, store, preserve, and reconstruct an event or object; 2) Manipulative Characteristics (Manipulative Property). This feature describes a presentation of events that can be accelerated or slowed down from the actual time of the event. For example, the process of butterfly metamorphosis can be accelerated by photographic recording techniques; 3) Distributive Property. This feature shows that the media can allow an object or event to be transported through space, and at the same time the event is presented to a large number of students with a relatively similar experience of the event.

Textbooks as media are an integral part of the learning system as a basis for policy in the selection of development and utilization. The function of the media in teaching activities is no longer a demonstration of the teaching staff but is a carrier of information or learning messages needed by students.

\section{CONCLUSION}

Based on some of the statements above, it can be concluded that a textbook is a concept or pattern based on local wisdom that is implemented in learning activities by following the procedures that have been made so that learning objectives can be achieved, learning activities are 
carried out on the basis of syntax, social systems, principles, reactions and support systems.

Textbooks are learning aids that are made based on the competencies that have been determined in the curriculum that must be achieved by students. Teaching textbooks are used to channel or convey messages with local wisdom-based education and learning objectives. Learning media are materials, tools, or methods or techniques used in teaching and learning activities, with the intention that the information process of educational communication between educators and students can take place in an effective and efficient manner.

\section{REFERENCES}

[1] Akyol \& Garrison. (2017). Handbook of Research on Innovative Pedagogies and Technologies for Online Larning in High Education. Vu, Phu, Fredrickson, Scott, Moore, Carl, (editor). Choclate Avenue, Hershey PA, USA: IGI Global

[2] Bogdan, R.C., \& Biklen, S.K (2007). Qualitative research for education. An introduction to theory and method. (5 $5^{\text {th }}$ ed). Boston: Pearson.

[3] Borg, R.W. and Gall, M, D,. (1983) Education research an introduction. Fourth Edition, New York : Longman.

[4] Boyd, R. D. (1994). Personal transformation in small groups: Part 1. Small Group Research, 20(4), 459-474.

[5] Confrey \& Maloney. (2016). Handbook of Technological Pedagogical Content Knowledge (TPACK) for Educators. Mary C. Herring, Matthew J. Koehler, Punya Mishr (editor). New York \& London: Routledge Taylor and Fancis Gorup.

[6] Dick, W. \& Carey, L. (2009). The systematic design of instruction. ( $5^{\text {th }}$ ed.). New York: Harper Collins Publishers.

[7] Gagne' R. M., Briggs, L. J., dan Wagner, W. W. (1988). Principles of Instructional Design. New York: Holt, Rinehart and Winston. Inc.

[8] Garrison dan Cleveland-Innes. (2005). Handbook of Research on Adult Learning in Higher Education. Okojie, Mabel C.P.O., Boulder, Tinukwa C. (editor). Choclate Avenue, Hershey PA, USA: IGI Global

[9] Gerlach, Vernon S., and Donald P. Ely, 1971, Teaching and media : A systematic approach, Prentice-Hall, Englewood Cliffs, N.J

[10] Good, T . L., \& Brophy, E. (1990). Educational psychology $\therefore$ A realistic approach. New York : Longman.

[11] Gustafson, K.L. 1981. Survey of Instrucyional Development Models. Syracuse, NY: Eric IR Document.

[12] Hergenhahn, B.R \& Olson, M.H. 2008. Theories of learning. Jakarta: Kencana

[13] Joyce, B. R. (1991). Models of teaching. Fourth Edition. Boston-London- Toronto- Sydney- Singapore: Allyn and Bacon Pulishers.

[14] Kegan, R. (2000). What form transforms? A constructivedevelopmental approach to transformative learning. Dalam J. Mezirow (Ed).) Learning as transformation: Critical perspective on a theory in progress. San Francisco, CA: Jossey-Bass.

[15] Keller, J.M. (1987). Development nd use of the ARSC model of instructional design. Journal of instructional development. September 1987, Volume 10, Issue 3, pp 210 .

[16] Lave \&Wneger. (2005). Beyond Communities of Practice: Language Power and Social Context. David Barton, Karin Tusting, (editor). New York: Cambrige University.

[17] Lickona, Thomas. (1991). Educating for Character: How Our School Can Teach Respect and Responsibility. New York, Toronto, London, Sydney, Aucland: Bantam books.

[18] Lickona, T., \& Davidson, M. (2005). Smart \& good high school: Integrating excellence an ethics for success in school, work, and beyond. Cortland, NY: SUNY Cortland, Center for the 4th and 5th Rs. Retrieved August 10, 2007, from http://www.cortland.edu/character/highschool/chapter/SnG 062105.pdf

[19] Loughran, J.J. (2002) Developing Reflective Practice: Learning About Teaching And Learning Through Modelling: Falmer Press.

[20] Mezirow, J. (2000). Learning as transformation: Critical perspectives on a theory in progress. San Francisco, CA: Jossey-Bass.

[21] Moon (2016). Reconceptualizing STEM Education: The Central Role of Practices. Richard A. Duschl, Amber S. Bismack (Editor). New York \& London : Routledge Taylor and Fancis Gorup

[22] Norbert M. Seel, Thomas Lehmann, Patrick Blumschein, Oleg A. Podolskiy Niess. (2017). Instructional Design for Learning: Theoretical Foundations. Rotterdam/Boston/Taipei: Sense Publishers

[23] Purkey, \& Smith, 1985. Too soon to cheer? Synthesis of research on effective schools. Educational Leadership.

[24] Richey, R. (1986). The theoretical and conceptual bases of instructional design. London: Kogan Page.

[25] Rogers, E. M. (2003). Diffusion of innovations (5th ed.). New York: Free Press

[26] Routledge, (2020) Expanding Transformation Theory: Affinities between Jack Mezirow and Emancipatory Educationalists. Alexis Kokkos (editor). New York \& London : Routledge Taylor and Fancis Gorup.

[27] Sztajn. (2017). Handbook of Research on Teacher Education and Professional Development. Martin, Christie, Polly, Drew, (editor). Choclate Avenue, Hershey PA, USA: IGI Global

[28] Sztajn, Confrey, Wilson, dan Edgington (2012). Learning Trajectories for Teachers: Designing Effective Professional Development for Math Instruction. Paola Sztajn, P. Holt Wilson, (editor). New York: Teacher College Press.

[29] UNDP, 2019: http://hdr.undp.org/en/content/table-1human-development-index-and-its-components-1

[30] Wendy Holmes. (2001). Speech Synthesis and Recognition $\left(2^{\text {nd }}\right)$ New York: Taylor \& Francis. 